\title{
NEUTRONIC AND THERMAL HYDRAULICS ANALYSIS OF CONTROL ROD EFFECT ON THE OPERATION SAFETY OF TRIGA 2000 REACTOR
}

\author{
Surian Pinem, Tukiran Surbakti, Iman Kuntoro \\ Center for Reactor Technology and Nuclear Safety - BATAN \\ Kawasan PUSPIPTEK Serpong Gd.80, Tangerang Selatan, Banten 15314 \\ e-mail: pinem@batan.go.id
}

(Naskah diterima: 21-08-2019, Naskah direvisi: 25-09-2019, Naskah disetujui: 18-10-2019)

\begin{abstract}
NEUTRONIC AND THERMAL HYDRAULICS ANALYSIS OF CONTROL ROD EFFECT ON THE OPERATION SAFETY OF TRIGA 2000 REACTOR. Analysis of neutronic and thermal-hydraulics parameters of whole operation cycle is very important for the safety of reactor operation. During the reactor operation cycle, the position of the control rods will change due to reactivity changes. The purpose of this study is to determine the effect of control rods position on neutronic and thermal-hydraulics parameters in relation to the safety of reactor operation of the TRIGA 2000 reactor using silicide fuel of MTR plate type. Those parameters are power peaking factor, reactivity coefficients, and steady-state thermohydraulic parameters. Neutronic calculations are performed using a combination of WIMSD/5 and Batan-3DIFF codes and for thermal-hydraulics the calculations are done using WIMSD/5 and MTRDYN codes. The calculation results show that the reactivity coefficient values are negative for all control rod positions both at CZP and HFP conditions. The MTC value decreases when the control rod is inserted into the active core while the FTC value increases. The total ppf results and temperature in steady-state rise when the control rods are inserted of into the active core whereby the maximum value occurs at the position of the control rods of $20 \mathrm{~cm}$ from the bottom of the active core. The calculation results of ppf, reactivity coefficient, and thermal-hydraulics parameters lay below safety limits, indicating that the TRIGA 2000 reactor can safely use $\mathrm{U}_{3} \mathrm{Si}_{2}-\mathrm{Al}$ silicide fuel as a substitute fuel for cylindrical type fuel.
\end{abstract}

Keywords: neutronic, thermal-hydraulic parameter, control rod effect, TRIGA 2000, silicide fuel. 


\section{ABSTRAK}

\section{ANALISIS NEUTRONIK DAN TERMOHIDRAULIK PENGARUH POSISI BATANG KENDALI} TERHADAP KESELAMATAN OPERASI REAKTOR TRIGA 2000. Analisis parameter neutronikdan termohidraulik dari seluruh siklus operasi sangat penting untuk keselamatan operasi reaktor. Selama siklus operasi reaktor, posisi batang kendali akan berubah karena perubahan reaktivitas. Tujuan dari penelitian ini adalah untuk mengetahui pengaruh posisi batang kendali terhadap parameter neutronik dan termohidraulik terkait keselamatan operasi reaktor TRIGA 2000 menggunakan bahan bakar silisida jenis MTR. Parameter yang ditentukan adalah faktor puncak daya, koefisien reaktivitas, dan parameter termohidraulika pada keadaan tunak. Perhitungan neutronikl dilakukan menggunakan kombinasi program WIMSD/5 dan Batan-3DIFF dan untuk termohidraulik dilakukan menggunakan program WIMSD/5 dan MTRDYN. Hasil perhitungan menunjukkan bahwa nilai koefisien reaktivitas negatif untuk semua posisi batang kendali baik pada kondisi CZP dan HFP. Nilai MTC berkurang ketika batang kendali dimasukkan ke teras aktif sementara nilai FTC meningkat. Hasil ppf total dan parameter dalam kondisi tunak meningkat dengan memasukkan batang kendali ke dalam teras aktif dimana nilai maksimum terjadi pada posisi batang kendali $20 \mathrm{~cm}$ dari bagian bawah teras aktif. Hasil perhitungan ppf, koefisien reaktivitas dan parameter termohidraulik berada di bawah batas keselamatan, ini menunjukkan bahwa reaktor TRIGA 2000 dapat menggunakan bahan bakar silisida $\mathrm{U}_{3} \mathrm{Si}_{2}-\mathrm{Al}$ dengan aman sebagai bahan bakar pengganti bahan bakar jenis silinder.

Kata kunci: neutronik, parameter termohidraulik, efek batang kendali, TRIGA 2000, bahan bakar silisida. 


\section{INTRODUCTION}

The Bandung TRIGA 2000 reactor currently uses cylindrical TRIGA fuel type and by now it is planned to be replaced by $\mathrm{U}_{3} \mathrm{Si}_{2}$-AI MTR fuel type. These TRIGA fuel types are no longer produced by General Atomic so, it comes an alternative to replace them with MTR fuel types. The $\mathrm{U}_{3} \mathrm{Si}_{2}-\mathrm{Al}$ silicide fuel with a density of $2.96 \mathrm{~g} / \mathrm{cc}$ is produced domestically by PT INUKI and used as RSG-GAS reactor fuel. For this reason, the calculation of the equilibrium core configuration has been carried out using the Batan-FUEL code[1]. The calculation results show that the reactor can be operated at a nominal power of $2 \mathrm{MW}$ using 16 fuels and 4 control rods[2-4]. One of the important problems with nuclear reactor operation is safety. A safety system is designed for control reactivity and prevent accidents[5]. The control rod and reactivity coefficient are factors that can control the reactor power.

In this study, the effect of control rods positions on neutronic and thermalhydraulic steady-state parameters will be calculated. The safety of reactor operation will be affected by core configuration, fuel fraction, type of fuel and fuel enrichment. During one cycle of reactor operation, the position of the control rod will change from the beginning of the cycle (BOC) to the end of cycle (EOC)[6]. The changes in the control rod positions will affect the reactor response to neutronic and thermal-hydraulic parameters. The control rods are generally used to control changes in reactivity, changes in power and to shut the reactor down[7]. The use of a control rod in a research reactor is different from a power reactor because the research reactor does not have a chemical shim rod to control reactivity[7]. The TRIGA reactor using MTR type fuel was designed to have 4 control rods for using as a compensation system. For this reason, the control rod position changes in one operating cycle may be significant enough to affect the safety of the reactor operation.

The parameters calculated in this study cover inherent safety parameters namely moderator temperature coefficient (MTC) and fuel temperature coefficient (FTC), as well as power peaking factor (ppf) and temperature at steady-state conditions. The inherent safety calculation is performed on the operating conditions cold zero power (CZP) and hot full power (HFP). Thermodynamic parameters due to the effect of the control rod position in the design of research reactors the MTR type is very important for safe operation and optimization of the fuel used[8,9]. This data is needed for the preparation of the safety analysis report (SAR) for the conversion of fuel from the cylinder type to the MTR type.

The code used in these calculations is the WIMSD/5[10], Batan-3DIFF[11] and MTR-DYN code[12,13]. The WIMSD/5 is used for the generation of macroscopic cross-sections of fuel elements, control elements, structural materials, reflector elements, and water. The WIMSD/5 and Batan-3DIFF code used for calculation of inherent safety parameters and ppf. Calculation of steady-state thermal-hydraulic parameters of equilibrium core is done by using WIMSD/5 and MTR-DYN code.

\section{DESCRIPTION OF TRIGA 2000}

The fuel element used in TRIGA 2000 is based on MTR technology and each standard fuel element consists of 21 fuel element plates. Each fuel element plate consists of an $\mathrm{AlMg}_{2}$ clad, which wrap the $\mathrm{U}_{3} \mathrm{Si}_{2}-\mathrm{Al}$ meat dispersion plate. The control rod is designed as a fork-type inserted in a so-calledcontrol element. The number of fuel plates in the control element is 15 fuel plates and in both outer sides are for the absorber Ag-In-Cd blades which are cladded by stainless steel (material 1.4541, the same as SS 321). The parameters of the fuel element and the control element of silicide fuel with a density of $2.96 \mathrm{~g} / \mathrm{cc}$ are shown in Table 1 . 
Equilibrium core configuration (TWC) of the TRIGA 2000 reactor is shown in Figure 1. The active core of TWC consists of 16 standard fuel elements, 4 control fuel elements, one irradiation position in the middle (CIP) and 4 irradiation positions (IP) inside the core. In addition to the arrangement of the reactor core $5 \times 5$, the reactor core is surrounded by a graphite reflector and in the graphite position, several irradiation facilities will be placed. The core parameters in the equilibrium core with the fuel loading pattern $4 / 1$ are presented in Table 2.

Table 1. Parameters of the mechanical design of fuel and control element of TRIGA 2000[2].

Fuel Elements and Control Elements

Types

Fuel Plates per Standard Fuel Element

Fuel Zone Thickness, mm

Fuel Zone Width, $\mathrm{mm}$

Fuel Zone Length, $\mathrm{mm}$

Type of Fuel

Enrichment, \%

Uranium Density in meat, $\mathrm{g} / \mathrm{cm}^{3}$

Cladding Thickness, mm (Rata-rata)

Cladding Thickness, mm (Minimum)

Cladding Material

Fuel Plate Thickness, $\mathrm{mm}$

Fuel Plate Width, $\mathrm{mm}$

Fuel Plate Width, $\mathrm{mm}$

Type of Absorber

Fuel Plates per Fuel Control Element

Material Absorber

Thickness, $\mathrm{mm}$

Cladding Material

MTR
21
0.54
62.75
600.0
$\mathrm{U}_{3} \mathrm{Si}_{2}-\mathrm{Al}$
19.75
2.96
0.38
0.25
$\mathrm{AlMg} 2$
1.3
70.75
625.0

Fork type with two absorber blades

15

AglnCd

3.38

Steels

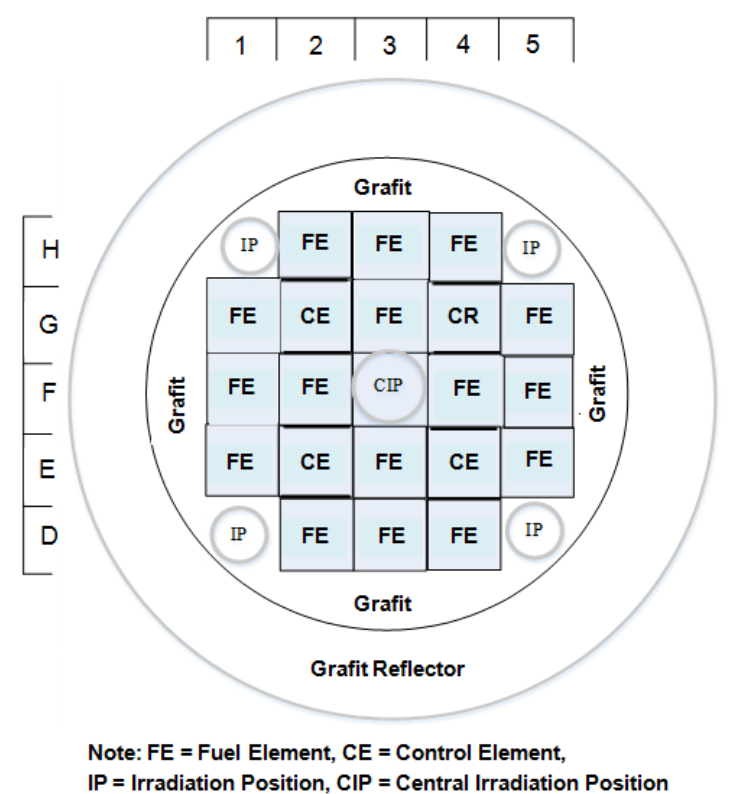

Figure 1. Equilibrium core TRIGA 2000 using $\mathrm{U}_{3} \mathrm{Si}_{2}-\mathrm{Al}$ fuel[2]. 
Table 2. Core parameters of the TRIGA2000 reactor using $\mathrm{U}_{3} \mathrm{Si}_{2}-\mathrm{Al}$ fuel[2].

\begin{tabular}{lc}
\hline Core parameters & Equilibrium core \\
\hline Massa ${ }^{235} \mathrm{U}$ per standard fuel element $(\mathrm{g})$ & 250 \\
Uranium density ( $\mathrm{g} / \mathrm{cc})$ & 2.960 \\
Power (MWth) / cycle length (days) & $2 / 120$ \\
Reactivity for one cycle $(\% \Delta k / k)$ & 2.183 \\
Excess reactivity $(\% \Delta k / k)$ & 6.61 \\
Total control rod values $(\% \Delta k / k)$ & -20.60 \\
Shutdown reactivity (stuck rod) $(\% \Delta k / k)$ & -6.56 \\
Power density (W/cc) & 28.305 \\
Average radial power peaking factor & 1.225 \\
Maximum discharged burn-up (\%) & 26.485 \\
Reactivity of control rod G-2 fully up, others fully down $(\% \Delta k / k)$ & -6.61 \\
Reactivity control rod G-4 fully up, others fully down $(\% \Delta k / k)$ & -6.56 \\
Reactivity of control rod E-2 fully up, others fully down $(\% \Delta k / k)$ & -6.61 \\
Reactivity of control rod E-4 fully up, others fully down $(\% \Delta k / k)$ & -6.60 \\
\hline
\end{tabular}

\section{METHODOLOGY}

\section{Core Calculation}

The neutronic core calculation core is performed at the equilibrium core using Batan-3DIFF. This Batan-3DIFF codes, have been developed in the Batan for neutronic design and safety analysis. This code solves the three-dimensional multigroup neutron diffusion problems. Batan-3DIFF codes have been validated and have high accuracy in designing the equilibrium silicide core for the RSG-GAS reactor[14]. The Batan-3DIFF was used to calculate criticality and core reactivity as a function of control rod positions to power peaking factor. The calculation is performed for the control rod positions of $0 \mathrm{~cm}$ (fully down), $10 \mathrm{~cm}, 20 \mathrm{~cm}$, $30 \mathrm{~cm}, 40 \mathrm{~cm}, 50 \mathrm{~cm}$ and $60 \mathrm{~cm}$ (fully up). The calculated data of axial and radial power peaking factor are needed for analysis of the thermal-hydraulic parameter calculations.

\section{Calculation of Reactivity Feedback Coefficient}

The reactivity coefficient is sometimes called the feedback reactivity coefficient which has a major influence on the safety of reactor operations[15]. Calculation of the feedback reactivity coefficient is done as a function of the position of the control rod. Cross-section calculations are performed using the WIMSD5 program in 4 (four) neutron energy groups. Calculation of fuel temperature coefficient, the cross-section is generated with changes in meat temperature from $20-200{ }^{\circ} \mathrm{C}$ and moderator temperature are kept constant at $20{ }^{\circ} \mathrm{C}$ for cold zero power conditions and $40{ }^{\circ} \mathrm{C}$ for hot full power conditions. Calculation of moderator coefficient temperature, moderator temperature is changed from $20-100{ }^{\circ} \mathrm{C}$ and fuel temperature are kept constant at 20 ${ }^{\circ} \mathrm{C}$ for cold zero power conditions and $68{ }^{\circ} \mathrm{C}$ for hot full power conditions.

Core calculation is performed using the combination of WIMS-D5 and Batan3DIFF codes. The moderator reactivity coefficient and the fuel reactivity coefficient are determined based on the keff value for each temperature as function of the control rod position.

The magnitude of the reactivity change per temperature change in a moderator, called the coefficient of temperature reactivity can be determined as follows: 
$\alpha_{\mathrm{m}}=\frac{\Delta \rho_{\mathrm{Tm}}}{\Delta \mathrm{T}_{\mathrm{m}}}$

where,

$\alpha_{m}$ : moderator coefficient temperature $\left(\mathrm{pcm} /{ }^{\circ} \mathrm{C}\right)$

$\Delta \rho_{\mathrm{m}}$ : reactivity change $(\mathrm{pcm})$

$\Delta \mathrm{T}_{\mathrm{m}}$ : moderator temperature change $\left({ }^{\circ} \mathrm{C}\right)$

The value of $\alpha_{T M}$ depends on the change in moderator temperature. Water moderated reactors have a negative $\alpha_{\text {TM }}$ value and will increase in value with an increase in water temperature. The fuel reactivity coefficient is defined as the change in reactivity per change temperature in fuel element which can be determined as follows:

$\alpha_{\mathrm{f}}=\frac{\Delta \rho_{\mathrm{f}}}{\Delta \mathrm{T}_{\mathrm{f}}}$

where,

$\alpha_{f}$ : fuel coefficient temperature $\left(\mathrm{pcm} /{ }^{\circ} \mathrm{C}\right)$

$\Delta \rho_{\mathrm{f}}$ : reactivity change ( $\left.\mathrm{pcm}\right)$

$\Delta \mathrm{T}_{\mathrm{f}}$ : moderator temperature change $\left({ }^{\circ} \mathrm{C}\right)$

The fuel temperature coefficient depends on the type and temperature of the fuel. Light water reactors generally have a negative fuel temperature coefficient where the reactivity will be reduced with an increase in fuel temperature.Change in reactivity was calculated as,

$\Delta \rho=\frac{k_{\mathrm{eff} 0-1}}{k_{\text {eff } 0}} \frac{\mathrm{k}_{\mathrm{efft}-1}}{\mathrm{k}_{\mathrm{efft}}}$

where, $\mathrm{k}_{\text {effo: }}$ : effective multiplication factors at reference temperature $20{ }^{\circ} \mathrm{C}$.

$\mathrm{k}_{\text {efft }}$ : effective multiplication factors at a specified temperature

Thermal Hydraulic Parameter Calculation

The calculation of thermal hydraulic parameter such as fuel temperature, cladding, and moderator as a function of the control rod is done using the MTR-DYN code. The MTR-DYN code depends on space and time, the diffusion theory of many groups is based on the steady-state analysis program and the transient MTR type research reactor. This program is designed for the transient model of research reactor criticality when additional reactivity and/or cooling system insertion occur. The MTRDYN code basically consists of a 3-dimensional model of neutronicthermohydraulic couplings which contains two main parts, the neutronic calculation module, and the thermohydraulic calculation module. The minimum flow rate of the primary cooling system is $70 \mathrm{~kg} / \mathrm{s}$ and only $59.5 \mathrm{~kg} / \mathrm{s}$ cools the reactor core. The core inlet temperature of $35{ }^{\circ} \mathrm{Cand}$ a pressure of 1.8 Mpa[16].

\section{RESULTS AND DISCUSSION}

\section{The Effect of Control Rod Position on ppf Axial and Radial}

Calculation results of radial and axial ppf as a function of the control rod are shown in Table 3.

Table 3. The maximum ppf value as a function of the control rod

\begin{tabular}{ccccc}
\hline Control rod position $(\mathrm{cm})$ & $\mathrm{k}_{\text {eff }}$ & Maximum ppf radial & Maximum ppf axial & ppf total \\
\hline 60 (fully up) & 1.0707938901 & 1.2132 & 1.2819 & 1.555201 \\
50 & 1.0643241450 & 1.1982 & 1.3848 & 1.659267 \\
40 & 1.0404020586 & 1.1791 & 1.5340 & 1.808739 \\
30 & 1.0026041081 & 1.1661 & 1.7135 & 1.998112 \\
20 & 0.9511311940 & 1.1684 & 1.8000 & 2.10312 \\
10 & 0.9025688629 & 1.1705 & 1.4116 & 1.652278 \\
0 (fully down) & 0.8849318170 & 1.1742 & 1.2755 & 1.497692 \\
\hline
\end{tabular}


Power peaking factor (ppf) is defined as maximum power divided by the average power in the reactor core or the ratio of maximum thermal neutron flux to mean neutron flux. High ppf value indicates that there is a high local power density in the reactor core. For the safety analysis of reactor operations, total ppf is used, which is a combination of axial and radial ppf values to guarantee that there is no damage to the fuel. Based on the data in Table 3, the maximum axial ppf values increase and as for the radial ppf decrease by increasing the control rod position to the core until the position is $20 \mathrm{~cm}$ from the bottom of the active core. The maximum total ppf value as a control rod position effect is still smaller than 3.00 which is used as a conservative value for reactor safety analysis.

\section{Moderator Temperatur Coefficient}

MTC is the function of the ratio of the moderator to fuel $\left(\mathrm{N}_{\mathrm{m}} / \mathrm{N}_{\mathrm{f}}\right)$ is the ratio of moderator atom density of the reactor to fuel atom density. For the reactor design the $\mathrm{N}_{\mathrm{m}} / \mathrm{N}_{\mathrm{f}}$ price in the reactor core is made optimum so that the moderating temperature coefficient is negative. The MTR type reactor is designed under an under moderator condition so that the $\mathrm{N}_{\mathrm{m}} / \mathrm{N}_{\mathrm{f}}$ decreases resulting in a reduced $\mathrm{k}_{\text {eff }}$. Changes in moderator temperature, without changes in density, resulting in increased resonance escape probability and reproduction factor $(\eta)$

Figure 2 shows the moderator temperature coefficient as a function of the control rod for the TRIGA 2000 core using $\mathrm{U}_{3} \mathrm{Si}_{2}-\mathrm{Al}$ silicide fuel. The MTC value in HFP conditions is more negative than CZP conditions because with the increase in temperature the moderator density decreases causing the neutrons to be at higher energy so that the probability of nonfission capture neutrons is increased. By reducing the $\mathrm{Nm} / \mathrm{Nf}$ ratio due to the increase in moderator temperature, the thermalization factor increases in the core.
Changes in the moderator temperature coefficient due to changes in control rods have a major effect. The effect of the control rod on MTC is when the control rod is inserted to the core the moderator density decreases resulting in reduced reactivity. The control rod absorbs thermal and epithermal neutrons causing the probability of leakage of thermal neutrons to decrease and then to increase negative reactivity. When the moderator temperature rises and a partially of the control rod is inserted to the core, the neutron spectrum tends to harden. When the neutron spectrum hardening the value of the control rod increases because the control rod has a high absorption cross-section for thermal and epithermal neutrons. For this reason, when the control rod is inserted into the active core, the MTC becomes more negative and when the control rod is withdrawal, the MTC becomes more positive. In addition, when the control rod is inserted into the core the $\mathrm{Nm} / \mathrm{Nf}$ decreases so that the core becomes under-moderated, resulting in a more negative MTC.

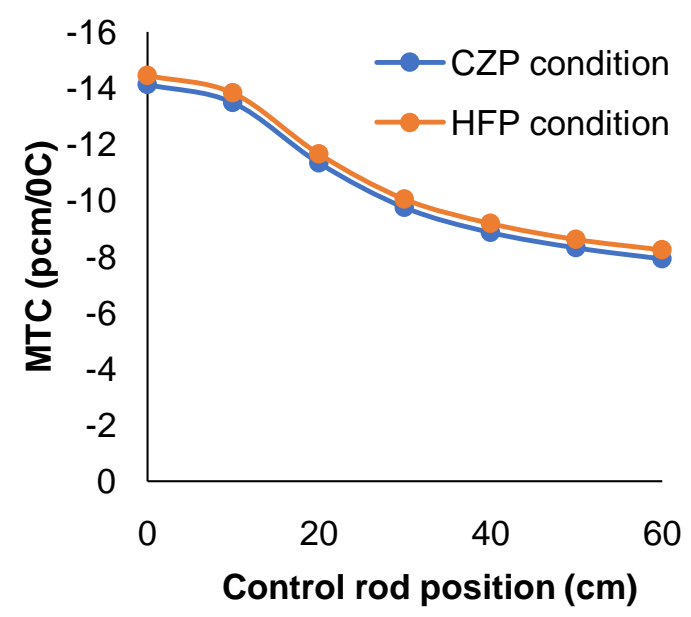

Figure 2. Effect control rod to moderator temperature coefficient

\section{Fuel Temperatur Coefficient}

The fuel temperature coefficient (FTC) and moderator temperature coefficient (MTC) are inherent safety features which are in the design of the reactor to produce 
negative reactivity due to increased power. In the low enrichment of thermal reactors, the contribution to the fuel temperature coefficient of reactivity comes from the Doppler broadening of the resonance capture cross-section of the fertile material. For this reason, the FTC is often called the Doppler reactivity coefficient, often abbreviated to Doppler. When the fuel temperature rises, the target energy has more energy so that fertile materials such as U-238 and Th-232 show large resonance peaks for neutron absorption and hence contribute to a large extent to the FTCThe results of the FTC calculation as a function of the control rod position are shown in Figure 3. The FTC value under the HFP operating conditions is more negative than the CZP condition. At high fuel temperatures, the resonance absorption peak for U-238 is broad, and most of the neutrons slowing down in the nucleus are captured in the resonant range.

The increase in temperature results in resonance absorption and the amount of thermal neutrons absorbed by $\mathrm{U}-235$ is small so that the effect of the FTC is smaller at high fuel temperatures. The withdrawal of the control rod from the bottom of active core results in an increase in the FTC because the moderator is replaced with an absorbent material so that the thermal utilization factor decrease and the neutron spectrum tend to harden. Changes in reactivity due to control rods were smaller at about $2.8 \%$ compared to when control rods were withdrawn from the active core.

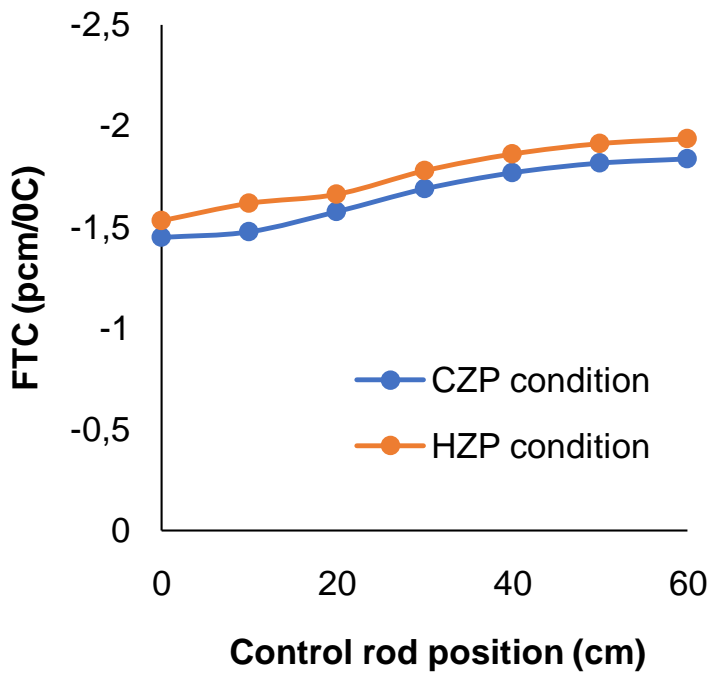

Figure 3. Effect control rod to fuel temperature coefficient

\section{Effect of Control Rods Positions on ThermalHydraulic Parameters}

Thermohydarulic analysis at steadystate conditions is very important for the safety of reactor operations. The results of the coolant, clad and fuel temperature calculations are shown in Table 4. Based on Table 4 the maximum temperature occurs when the control rod is $20 \mathrm{~cm}$ of the active core because in this condition the largest ppf occurs as shown in Table 3 . The calculation results show that the maximum coolant temperature is $52.56{ }^{\circ} \mathrm{C}$, cladding temperature is $90.85{ }^{\circ} \mathrm{C}$ and the fuel temperature is $91.08{ }^{\circ} \mathrm{C}$. Coolant temperature is still below $100{ }^{\circ} \mathrm{C}$ and cladding temperature is still smaller than $120^{\circ} \mathrm{C}$, so there is no boiling on the reactor core.

Table 4. Coolant, clad and fuel temperature as a function of control rod position

\begin{tabular}{cccc}
\hline $\begin{array}{c}\text { Control rod position } \\
(\mathrm{cm})\end{array}$ & $\begin{array}{c}\text { Coolant temperature } \\
\left({ }^{\circ} \mathrm{C}\right)\end{array}$ & $\begin{array}{c}\text { Clad temperature } \\
\left({ }^{\circ} \mathrm{C}\right)\end{array}$ & $\begin{array}{c}\text { Fuel temperature } \\
\left({ }^{\circ} \mathrm{C}\right)\end{array}$ \\
\hline 60 (fully up) & 51.70 & 81.27 & 81.45 \\
50 & 51.71 & 83.49 & 83.68 \\
40 & 51.91 & 86.92 & 87.13 \\
30 & 52.03 & 90.41 & 90.63 \\
20 & 52.20 & 90.85 & 91.08 \\
10 & 52.41 & 82.83 & 83.01 \\
0 (fully down) & 52.56 & 83.37 & 83.56 \\
\hline
\end{tabular}




\section{CONCLUSION}

The maximum axial ppf and total ppf values occur at the position of the control rod $20 \mathrm{~cm}$ from the bottom of the active core. MTC and FTC values at all control rod positions are negative, which show that the results are very good from the safety aspect of reactor operation. The average MTC change due to the changes in the position of the control rod increased by $12 \%$ due to the insertion of the control rod in the core. Meanwhile, changes in the FTC were not significant with changes in the control rod position. In thermal hydraulics conditions the coolant, cladding, and fuel temperatures are still below the permitted temperature so that the reactor operates safely.

\section{ACKNOWLEDGMENT}

The authors thank the Head of PTKRN and Dr. Syaiful Bakhri as the head of the Reactor Physics and Technology Division, PTKRN-BATAN, for their cooperation in this research. This research was supported by the fiscal years of 2018 (DIPA 2018).

\section{REFERENCES}

[1] P. H. Liem, "Development and verification of Batan's Standard, twodimensional multigroup neutron diffusion code," Atom Indonesia Journal, vol. 20, no. 1, pp. 1-19, 1994.

[2] S. Pinem, T. M. Sembiring, and T. Surbakti, "Core conversion design study of TRIGA Mark 2000 Bandung using MTR plate type fuel element," International Journal of Nuclear Energy Science and Technology, vol. 12, no. 3, pp. 222-238, 2018.

[3] S. Pinem, T. Surbakti, and T. M. Sembiring, "Core design TRIGA 2000 Bandung using U3Si2Al fuel element MTR Type," Urania Jurnal IImiah Daur Bahan Bakar Nuklir, vol. 24, no. 2, pp. 93-103, 2018.

[4] T. Surbakti, S. Pinem, and S. Bakhri,
"Sensitivity of reflector on neutronic parameter for conversion core design of the TRIGA Research Reactor," Journal of Physics: Conference Series, vol. 1198, no. 2, 2019.

[5] M. Rahgoshay and O. Noori-Kalkhoran, "Calculation of control rod worth and temperature reactivity coefficient of fuel and coolant with burn-up changes for VVRS-2 MWth nuclear reactor," Nuclear Engineering and Design, vol. 256, pp. 322-331, 2013.

[6] H. Omar, K. Haddad, N. Ghazi, and N. Alsomel, "Experimental and operational validation of burn-up calculations for the Syrian MNSR," Progress in Nuclear. Energy, vol. 52, no. 8, pp. 753-758, 2010.

[7] M. Torabi, A. Lashkari, S. F. Masoudi, and S. Bagheri, "Neutronic analysis of control rod effect on safety parameters in Tehran Research Reactor," Nuclear Engineering and Technology, vol. 50, no. 7, pp. 1017-1023, 2018.

[8] S. Pinem, L. Suparlina, and T. Surbakti, "Effect Of U-9Mo/Al fuel densities on neutronic and steady state thermal hydraulic parameters of MTR type Research Reactor," Energy, 2016, vol. 1, no. 1, pp. 1-9.

[9] R. Nazar, K.A. Sudjatmi, and K. Kamajaya, "The thermohydraulic analysis of the Bandung Research Reactor core with plate type fuel elements using the CFD code," Tri Dasa Mega, vol. 20, no. 3, p. 123, 2018.

[10] WIMSD5, "Deterministic Multigroup Reactor Lattice Calculations, NEA1507/04." 2004.

[11] P. H. Liem and T. M. Sembiring, "Design of transition cores of RSG GAS (MPR-30) with higher loading silicide fuel," Nuclear Engineering and Design, vol. 240, no. 6, pp. 1433-1442, 2010.

[12] S. Pinem, T. M. Sembiring, and P. H. Liem, "Neutronic and thermal-hydraulic safety analysis for the optimization of 
the uranium foil target in the RSG-GAS Reactor," Atom Indonesia Journal., vol. 42, no. 3, pp. 123-128, 2016.

[13] T. Surbakti, S. Pinem, T. M. Sembiring, M. Subekti, and G. R. Sunaryo, "Preliminary study for the alternative conceptual core design of the MTR research reactor," Journal of Physics: Conference Series, vol. 962, no. 1, 2018.

[14] T. M. Sembiring, Tukiran, and S. Pinem, "Neutronic design of mixed oxide-silicide cores for the core conversion of RSG-GAS Reactor," Atom Indonesia Journal, vol. 27, no. 2, pp. 85-1001, 2001.

[15] M. Albarhoum, "Progress in nuclear energy thermalhydraulics and safety aspects of the use of monolithic U-9Mo LEU fuel in the low-power reactors," Progress in Nuclear. Energy, vol. 52, no. 6, pp. 536-540, 2010.

[16] E. P. Hastuti, S. Widodo, M. Darwis Isnaini, G. S. Sunaryo, and S. Bakhri, "Determining Coolant Flow Rate Distribution in the Fuel-Modified TRIGA Plate Reactor," Journal of Physics: Conference Series, vol. 962, no. 1, 2018. 